\title{
Serological detection of antibodies against Paracoccidioides brasiliensis in dogs with leishmaniasis
}

\author{
L.H. Silveira ${ }^{1,2}$, I.H. Domingos ${ }^{3}$, K. Kouchi ${ }^{3}$, E.N. Itano ${ }^{1}$, E.A. Silva ${ }^{3}$, \\ V.O. Landgraf ${ }^{4}$, S.M. Werneck ${ }^{4}$, Z.P. Camargo ${ }^{5}$ \& M.A. Ono ${ }^{1}$ \\ ${ }^{1}$ Departamento de Ciências Patológicas, Centro de Ciências Biológicas, Universidade Estadual de Londrina, \\ Campus Universitário, Londrina, PR, 86051-980, Brazil; ${ }^{2}$ Faculdades Luiz Meneghel, Bandeirantes, PR, \\ Brazil; ${ }^{3}$ Centro de Controle de Zoonoses, Secretaria da Saúde, Campo Grande, MS, Brazil; ${ }^{4}$ Laboratório \\ Central (LACEN), Fundação da Saúde do Mato Grosso do Sul, Campo Grande, MS, Brazil; ${ }^{5}$ Disciplina de \\ Biologia Celular, Universidade Federal de São Paulo, São Paulo, Brazil
}

Received 3 March 2006; accepted in revised form 20 July 2006

\begin{abstract}
The aim of this study was to detect antibodies against Paracoccidioides brasiliensis in dogs seropositive and seronegative for leishmaniasis. Sera from $836 \mathrm{dogs}$ (449 positive and 387 negative to leishmaniasis) were analysed by ELISA and the immunodiffusion test using gp43 and exoantigen, respectively. The analysis of the 836 serum samples by ELISA and the immunodiffusion test showed a positivity of $67.8 \%$ and $7.3 \%$, respectively, for $P$. brasiliensis infection. The dogs positive to leishmaniasis showed a higher reactivity to gp43 $(79.9 \%)$ and exoantigen $(12.7 \%)$ than the negative ones $(54.0 \%$ and $1.0 \%$, respectively). The higher reactivity to $P$. brasiliensis antigens may be due to cross-reactivity or a co-infection of dogs by Leishmania and $P$. brasiliensis. The lower correlation $(0.187)$ observed between reactivity to gp43 and Leishmania antigen reinforces the latter hypothesis.
\end{abstract}

Key words: dog, ELISA, Leishmania, Paracoccidioides brasiliensis

\section{Introduction}

Paracoccidioidomycosis is a systemic mycosis endemic in Latin American countries. The etiologic agent Paracoccidioides brasiliensis is a thermodimorphic fungus that grows as yeast in the host either at $37^{\circ} \mathrm{C}$ and as mycelia at $25^{\circ} \mathrm{C}$.

The individuals that develop PCM are mainly male agricultural workers. The granulomatous lesions are frequently observed in lungs, lymphonodes, spleen, liver, skin and mucosa. The infection probably occurs by fungus propagule inhalation [1].

The ecoepidemiological aspects of PCM remains poorly understood. Despite several attempts to find the $P$. brasiliensis habitat, until now it is unknown although it is believed that the fungus lives in soil [2]. The role of other animal species in the fungus ecology also remains unclear. $P$. brasiliensis was isolated from frugivorous bats [3], penguin [4] and armadillos [5-8].

Epidemiological studies suggest that other species such as cows [9], horses [10] sheep [11], monkeys [12] and dogs [13, 14] may be infected by $P$. brasiliensis. High levels of $P$. brasiliensis infection were observed in dogs from Southern and South-eastern regions of Brazil [14, 15]. The habits of sniffing and digging the soil could increase the chance of dogs being infected. The first case of natural paracoccidioidomycosis in dogs was reported recently [16]. 
Taking into account that endemic areas for paracoccidiodomycosis can be endemic for other diseases that affect dogs such as leishmaniasis, the aim of this study was to evaluate the infection by $P$. brasiliensis in dogs seropositive and seronegative for leishmaniasis.

\section{Materials and methods}

\section{Area of study}

The municipality of Campo Grande (latitude $2026^{\prime} 34^{\prime \prime} \mathrm{S}$, longitude $5438^{\prime} 47^{\prime \prime} \mathrm{W}$, altitude $542 \mathrm{~m}$ ) is located in Mato Grosso do Sul State, Midwestern Brazil (Figure 1). The climate is tropicalhumid with mean annual temperatures of $26^{\circ} \mathrm{C}$ and relative humidity of $73 \%$. The rainfall is around $1500 \mathrm{~mm}$ per year, the rainy season is from September to March (annual mean). The predominant soils are medium to heavy clay.

\section{Animals}

Approximately 20,000 serum specimens were collected from dogs in the suburbs of Campo Grande. The dogs were sampled from May 2003 to May

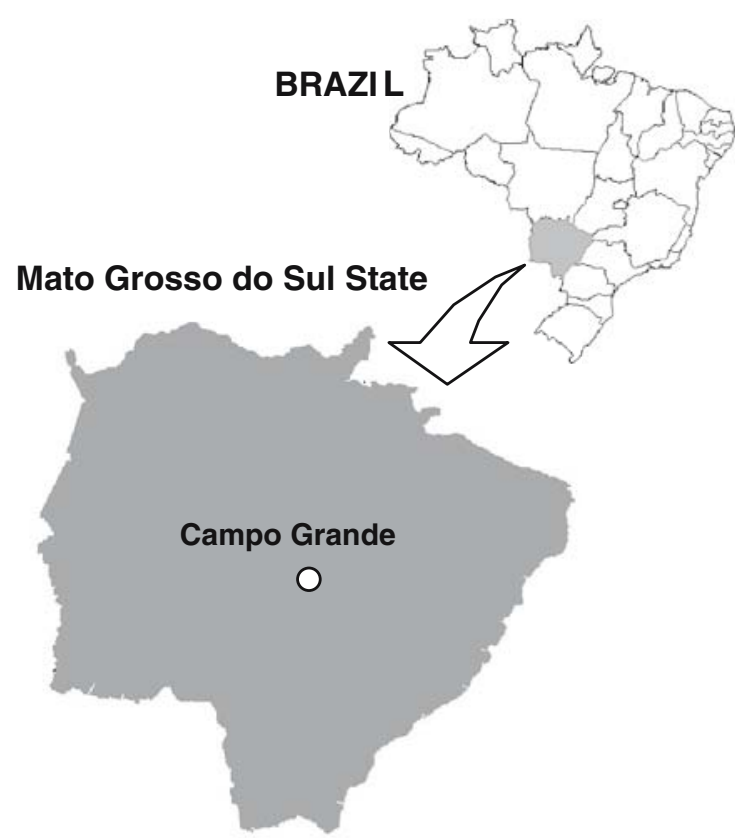

Figure 1. Map showing the location of the municipality of Campo Grande, Mato Grosso do Sul State.
2004 for leishmaniasis diagnosis and for this study 836 serum samples were randomly selected as follows: 449 samples seropositive and 387 samples seronegative for leishmaniasis.

\section{Paracoccidioides brasiliensis antigens}

\section{Exoantigen}

The exoantigen was obtained as described by Camargo et al. [17], using the P. brasiliensis isolate B-339.

\section{Antigen gp43}

The gp43 was purified from the $P$. brasiliensis exoantigen by affinity chromatography as previously described by Puccia and Travassos [18]. The protein concentration was determined by the Bradford method using BSA as standard [19].

\section{ELISA for leishmaniasis diagnosis}

Leishmaniasis was diagnosed by a commercial ELISA kit (Bio-Manguinhos, Rio de Janeiro, RJ, Brazil). The test was carried out according to the manufacturer's instructions.

\section{ELISA for anti-gp43 antibodies detection}

The sera were analysed for detection of anti-gp43 antibodies as previously described by Eisele et al. [20]. In brief, polystyrene flat-bottom microtiter plates (Corning Costar Corporation, Corning, NY, USA) were coated with gp43 in $0.1 \mathrm{M}$ carbonate buffer, $\mathrm{pH} 9.6\left(250 \mathrm{ng}\right.$ well $\left.^{-1}\right)$. The plates were washed with phosphate-buffered saline (PBS) containing $0.1 \%$ Tween 20 and blocked with PBST 5\% skim milk (PBS-T-M). After washing PBS$\mathrm{T}$, the serum samples were diluted 1:100 in PBS $1 \%$ skim milk (PBS-M) and incubated at $37{ }^{\circ} \mathrm{C}$ for $1 \mathrm{~h}$. The plates were washed and incubated at $37^{\circ} \mathrm{C}$ for $1 \mathrm{~h}$ with anti-dog IgG-peroxidase conjugate (Sigma, St Louis, MO, USA). After washing with PBS-T the solution of substrate/ chromogen $\left(\mathrm{H}_{2} \mathrm{O}_{2} /\right.$ tetramethylbenzidine $)$ was added to each well, and the reaction was stopped with $4 \mathrm{~N} \mathrm{H}_{2} \mathrm{SO}_{4}$. Absorbance was measured with an ELISA reader at $450 \mathrm{~nm}$. The positive and 
negative controls were a serum sample from a dog immunized with $P$. brasiliensis and a pool of sera from urban dogs, respectively. Sera with two-fold or more the absorbance of the negative control were considered positive.

\section{Immunodiffusion test}

The test was performed as previously described by Eisele et al. [20] using P. brasiliensis exoantigen as reagent. The serum from a dog immunized with P. brasiliensis was used as a positive control.

\section{Clinical exam of dogs positive in immunodiffusion test}

Four animals positive in the immunodiffusion test were examined for PCM clinical signs (fever, lymph node enlargement, cough and other respiratory signs). These animals were also submitted to a chest X-ray.

\section{Statistical analysis}

The statistical analysis was performed with the program EpiInfo ${ }^{\circledR}$ 6.0. The difference was considered significant when $P$ was less than 0.05 .

\section{Results and discussion}

The analysis of the 836 dog serum samples by ELISA and the immunodiffusion test showed a positivity of 67.8 and $7.3 \%$, respectively for $P$. brasiliensis infection (Table 1). The higher positivity observed in ELISA may be due to the greater sensitivity of this test. A seroepidemiological study carried out to determine the prevalence of $P$. brasiliensis antibodies in Brazilian blood donors showed positivity of $21 \%$ by ELISA with g43 antigen, but no reactivity was detected by immunodiffusion test [21].

Table 1. Reactivity of dogs' sera against $P$. brasiliensis antigens gp43 and exoantigen evaluated by ELISA and immunodiffusion

\begin{tabular}{lll}
\hline Sex & gp43 (ELISA) \% & Exoantigen (ID) \% \\
\hline Male & 67.9 & 8.6 \\
Female & 67.7 & 5.8 \\
Total & 67.8 & 7.3 \\
\hline
\end{tabular}

ID $=$ Immunodiffusion.
The differences in positivity were not statistically significant in relation to sex by either test (Table 1) suggesting that male and female dogs are equally exposed to the $P$. brasiliensis infection.

Similar results were observed by our group in a seroepidemiological study with dogs from rural and urban areas although no reactivity was observed in the immunodiffusion test [14]. The infection of $\operatorname{dogs}$ by $P$. brasiliensis was also investigated by Mós and Fava Netto [13]. The authors observed a positivity of $75 \%$ in dogs from the State of São Paulo, Brazil, using the complement fixation test with the $P$. brasiliensis polysaccharide antigen.

The dogs that showed reactivity in the immunodiffusion test probably have developed paracoccidioidomycosis because in human paracoccidiodomycosis, only patients with clinical symptoms are reactants in this test [17]. Four out of 61 dogs positive in the immunodiffusion test were examined in search of clinical signs of paracoccidioidomycosis. Discrete radiological alterations were observed in two dogs (data not shown). Probably these animals were in an initial phase of paracoccidiodomycosis with very discreet signs of illness. Recently, our group has reported an experimental infection of dogs with P. brasiliensis and all animals had shown humoral immune response although no significant alteration had been observed in thoracic X-ray [20].

Unfortunately the following of a greater number of animals was not possible because the serologic tests to evaluate infection by $P$. brasiliensis were carried out after the euthanasia of dogs positive for leishmaniasis.

The dogs positive for leishmaniasis showed a higher reactivity to gp43 (79.9) than the negative ones $(54 \%)$ (Table 2$)$. Similar results were observed in the immunodiffusion test taking into account that $12.7 \%$ of the samples positive to

Table 2. Reactivity of dogs' sera seropositive and seronegative for leishmaniasis against $P$. brasiliensis antigens gp43 and exoantigen evaluated by ELISA and immunodiffusion

\begin{tabular}{lll}
\hline & gp43 (ELISA) \% & Exoantigen (ID) \% \\
\hline $\begin{array}{l}\text { Leishmaniosis } \\
\text { positive }(n=449)\end{array}$ & $79.9(n=359)$ & $12.7(n=57)$ \\
$\begin{array}{l}\text { Leishmaniosis } \\
\text { negative }(n=387)\end{array}$ & $54.0(n=209)$ & $1.0(n=4)$ \\
\hline
\end{tabular}

ID $=$ Immunodiffusion. 
leishmaniasis were positive for $P$. brasiliensis exoantigen against only $1.0 \%$ for the leishmaniasis negative samples (Table 2).

This higher reactivity to $P$. brasiliensis antigens observed in serum samples positive to leishmaniasis may suggest a cross reactivity with Leishmania antigens as previously described [22]. In order to rule out this hypothesis a correlation test was performed to compare reactivity of serum samples to P. brasiliensis (gp43) and Leishmania antigens. The very low correlation coefficient observed $(r=0.187)$ suggests that reactivities against the two antigens systems are not related (Figure 2). Taking into account that the municipality of Campo Grande is endemic for paracoccidioidomycosis [23] and leishmaniasis [24], dogs at higher risk of infection by Leishmania could be also more exposed to $P$. brasiliensis infection.

The dogs under 1-year-old showed lower reactivity to gp43 suggesting that the age is a risk factor for P. brasiliensis infection (Figure 3). Older animals have a higher probability of being infected by the fungus during their lifetime. Otherwise the puppies that are at lower risk of infection are probably more susceptible to developing paracocccidioidomycosis than adults [25].

The data of this study suggest that co-infection of dogs by P. brasiliensis and Leishmania may be occurring. The association between these pathogens in dogs is very interesting because the protective immune response to paracoccidioidomy-cosis and leishmaniasis is TH1 type [26, 27]. In this way, dogs susceptible to developing leishmaniasis could be also more susceptible to developing paracoccidioidomycosis.

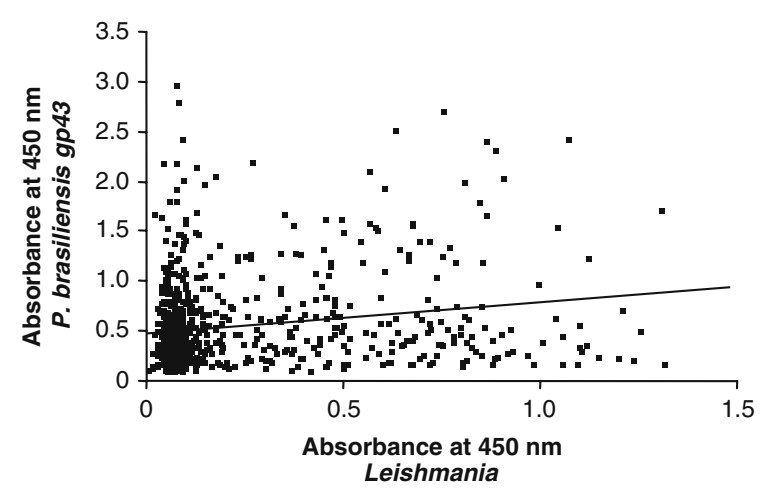

Figure 2. Correlation between absorbances of dogs' sera analysed by ELISA for reactivity to antigens from Leishmania and P. brasiliensis (gp43).

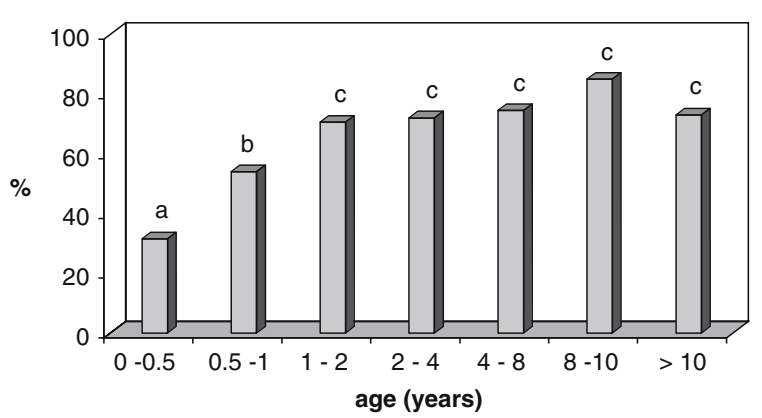

Figure 3. Relative frequency of positivity against gp43 evaluated by ELISA in dog serum samples $(n=836)$ according to age.

\section{Acknowledgements}

The authors thank CNPq, CAPES and Araucaria Foundation for financial support and Dr. Roberta Lemos Freire for aid with statistical analysis.

\section{References}

1. Restrepo A. The ecology of Paracoccidioides brasiliensis: A puzzle still unsolved. Sabouraudia 1985; 23: 323-334.

2. Albornoz MB. Isolation of Paracoccidioides brasiliensis from rural soil in Venezuela. Sabouraudia 1971; 2: 248251.

3. Grose E, Tamsitt JR. Paracoccidioides brasiliensis recovered from intestinal tract of three bats (Artibeus lituratus) in Colombia, SA. Sabouraudia 1965; 4: 124-125.

4. Gezuele E. Aislamiento de Paracoccidioides brasiliensis de heces de pinguino de la Antardida. IV Encuentro Internacional sobre Paracoccidioidmicosis, Caracas . Venezuela: Instituto Venezuelano de Investigaciones Cientificas (IVIC), 1989Abstract B-2.

5. Naiff RD, Ferreira LCL, Barret TV et al. Enzootic paracoccidioidomycosis in armadillos (Dasypus novemcinctus) in the State of Para. Rev Inst Med Trop São Paulo 1986; 28: 19-27.

6. Bagagli E, Sano A, Coelho KL et al. Isolation of Paracoccidioides brasiliensis from armadillos (Dasypus novemcinctus) captured in an endemic area of paracoccidioidomycosis. Am J Trop Med Hyg 1998; 58: 505-512.

7. Corredor GG, Castaño JH, Peralta LA et al. Isolation of Paracoccidioides brasiliensis from the nine-banded armadillo Dasypus novemcinctus, in an dendemic area for paracoccidioidomycosis in Colombia. Rev Iberoam Micol 1999; 16: 216-220.

8. Silva-Vergara ML, Martinez R, Camargo ZP, Malta $\mathrm{MHB}$ et al. Isolation of Paracoccidioides brasiliensis from armadillos (Dasypus novemcinctus) in an area where the fungus was recently isolated from soil. Med Mycol 2000; 38: 193-199.

9. Gutierrez AH, Ceballos GC, Ferrer HIP et al. Encuesta sobre tuberculosis, histoplasmosis y paracoddioidomycosis 
en ganado lechero del valle del Aburra. Antioq Med 1974; 24: 339-358.

10. Conti-Diaz IA, Avarex BJ, Gezuele E et al. Encuesta mediante intradermoreacciones com paracoccidioidina y histoplasmina em caballos. Rev Inst Med Trop São Paulo 1972; 14: 372-376.

11. Costa EO, Fava-Netto C. Contribution to the Epidemiology of paracoccidioidomycosis and histoplasmosis in the state of São Paulo, Brazil. Paracoccidioidin an histoplasmin intradermic tests in domestic animals. Sabouraudia 1978; 16: 93-101.

12. Johnson WD, Lang CM. Paracoccidioidomycosis (South American blastomycosis) in squirrel monkey (Saimiri sciureus). Vet Pathol 1977; 14: 368-371.

13. Mós EN, Fava-Netto C. Contribuição ao estudo da paracoccidoidomicose - I. Possível papel dos cães. Estudo sorológico e anatomo-patológico. Rev Inst Med Trop São Paulo 1974; 16: 154-159.

14. Ono MA, Bracarense APFRL, Morais HSA et al. Canine paracoccidoidomycosis: A seroepideiologic study. Med Mycol 2001; 39: 277-282.

15. Fagundes RQ, Araújo Jr. JP, Modolo R, Bagagli E. Serological Detection of Paracoccidioidomycosis in Dogs from the Endemic Area of Botucatu-SP, Brazil. ARBS, Pirenópolis-GO, Brasil, 2002.

16. Ricci G, Mota FT, Wakamatsu A et al. Canine paracoccidioidomycosis. Med Mycol 2004; 42: 379-383.

17. Camargo ZP, Unterkircher C, Campoy SP, Travasso LR. Production of Paracoccidioides brasiliensis exoantigens for immunodiffusion test. J Clin Microbiol 1988; 26: 2147 2151.

18. Puccia R, Travassos LR. The $43 \mathrm{kDa}$ glycoprotein from the human pathogen Paracoccidioides brasiliensis and its deglycosylated form: Excrection and susceptibility to proteolysis. Arch Biochem Biophys 1991; 289: 298-302.

19. Bradford MM. A rapid and sensitive method for the quantitation of microgram quantities of protein utilizing the principle of protein-dye binding. Anal Biochem 1976; 72: 248-254.

20. Eisele RC, Juliani LC, Belitardo DR et al. Immune response in dogs experimentally infected with Paracoccidioides brasiliensis. Med Mycol 2004; 42: 549-553.
21. Botteon FA, Camargo ZP, Benard G, Coelho RF, Chamone DA, Itano EN. Paracoccidioides brasiliensisreactive antibodies in Brazilian blood donors. Med Mycol 2002; 40: 387-391.

22. Suzuki E, Toledo MS, Takahashi HK et al. A monoclonal antibody directed to terminal residue of beta-galactofuranose of a glycolipid antigen isolated from Paracoccidioides brasiliensis: cross-reactivity with Leishmania major and Trypanosoma cruz. Glycobiology 1997; 7: 463-468.

23. Paniago AM, Aguiar JI, Aguiar ES, da Cunha RV, Pereira GR, Londero AT, Wanke B. Paracoccidioidomycosis: a clinical and epidemiological study of 422 cases observed in Mato Grosso do Sul. Rev Soc Bras Med Trop 2003; 36: 455-459.

24. Andreotti R, Oliveira JM, Silva EA, Oshiro LM, Matos MFC. Occurrence of Neospora caninum in dogs and its correlation with visceral leishmaniasis in the urban area of Campo Grande, Mato Grosso do Sul, Brazil. Vet Parasitol 2006; 135: 375-379.

25. Ono MA, Kishima MO, Itano EN et al. Experimental paracoccidoidomycosis in dogs. Med Mycol 2003; 41: 265-268.

26. Kashino SS, Fazioli RA, Cafalli-Favati $\mathrm{C}$ et al. Resistance to Paracoccidioides brasiliensis infection is linked to a preferential Thl immune response, whereas susceptibility is associated with absence of IFN-gamma production. J Interferon Cytokine Res 2000; 20: 89-97.

27. Lemesre JL, Holzmuller P, Cavaleyra M et al. Protection against experimental visceral leishmaniasis infection in dogs immunized with purified excreted secreted antigens of Leishmania infantum promastigotes. Vaccine 2005; 23: 2825-2840.

Address for correspondence: M. A. Ono, Universidade Estadual de Londrina, Departamento de Ciências Patológicas, Centro de Ciências Biológicas, Campus Universitário, Londrina, Paraná 86051-980, Brazil

Fax: + 55-43-3371-4267

E-mail: marioono@uel.br 